Mr. Selwyn TAYlor: What I meant was, how could you make a firm diagnosis of malignancy in a tumour where one sees every kind of undifferentiated tissue? Is it not the future development of a tumour which tells you whether it is malignant in that particular person?

Dr. Harrison: The answer to that is the experience and knowledge of previous cases. It has been worked out over hundreds of cases that certain patterns of cytology have in the past been associated with certain patterns of behaviour.

Mr. Selwyn Taylor: Would you call this an embryoma?

DR. HARRISON: I do not like the word; I think anaplastic teratoma is better. In the growth of tissue there are involved what Needham and others have described as organizers, the primary organizers regulating the relationships of individual types of tissue, and these are at fault in teratomata.
As regards Prof. Aird's point about dysgerminoma, there are two schools of thought in this connection. Chevaux, who described the original seminoma in the testis, described it as a malignant carcinoma. James Ewing, of New York, belongs to the other school who holds that the seminoma and dysgerminoma are themselves teratomata and are not carcinomas. Willis belongs to the Chevaux school. Here we have a very fair example of what $I$ think can be a reasonable diagnosis of dysgerminoma occurring in relation to an obvious teratoma. This has also been described by Willis in the testis.

Mr. Graber: Should she not have a course of $\mathrm{X}$-ray therapy?

Mr. Selwyn Taylor: I think Professor Young should perhaps make the final decision. Indeed the decision is a hard one, because X-rays will destroy the function of the single remaining ovary.

\title{
Abdominal Tuberculosis in Middle Life
}

\section{Case History (O. Daniel)}

The patient, a married woman of 59 , was admitted from another hospital complaining of sinuses in the neck for ten years and of progressive swelling of the abdomen for the past two months.

She had had 24 years previously a thrombosis of the inferior vena cava, not related to pregnancy or to other illness. Since then she had had varicose veins on her legs and abdomen.

The uterus and one ovary were removed 22 years ago, the patient believes, for ' fibroids.' There was no relevant family history.

On examination. The patient was thin and looked older than her stated age. On the left side of the neck were several thin, white scars marking the sites of sinuses which had developed some years previously (Fig. I). On the right side of the neck were several areas of incrustation surrounded by unhealthy blue skin (Fig. 2). There were similar sinuses and a firm fixed mass $4 \mathrm{~cm}$. by $3 \mathrm{~cm}$. in size in the right axilla. The abdomen was distended and showed numerous distended tortuous subcutaneous veins in which the blood flow was upwards (Figs. 3 and 4 ). A considerable degree of ascites was present and there was a large firm fixed mass in the upper abdomen. No abnormality was detected on vaginal or rectal examination.

Operations. (I) April 3, I950. The mass in the axilla was excised and found to contain caseous material surrounded by dense fibrosis. The lining of the neck sinus was curetted. The tissues obtained were reported to show evidence of tuberculosis. Ascitic fluid was aspirated and was found to contain cells strongly suggesting a mucinsecreting carcinoma.

(2) April I7, 1950. Laparotomy. A large mass was found in the epigastrium. The small and large bowel were studded with millet-seed bodies. One of these was removed for histological examination. The laparotomy findings were strongly suggestive of carcinomatosis.

\section{Pathology (Dr. C. V. Harrison)}

The first specimen from this patient was ascitic fluid. In this we found a few large cells containing demonstrable mucin. Although the individual cells did not appear to be malignant their content of mucin made us very suspicious of the presence of a mucin-secreting carcinoma within the abdomen. This has since proved to be wrong and our finding was misleading.

The second specimen was the curettings from the sinus in the neck. These consisted of typical tuberculous granulation tissue with caseation, epitheloid cells and giant cells, often in follicles.

The third specimen was the excised sinus from the axilla. This was an ellipse of skin $15 \mathrm{~mm}$. by I $8 \mathrm{~mm}$. with a small sinus in the middle. A transverse section of the sinus just under the skin showed a small track containing caseating tubercu- 


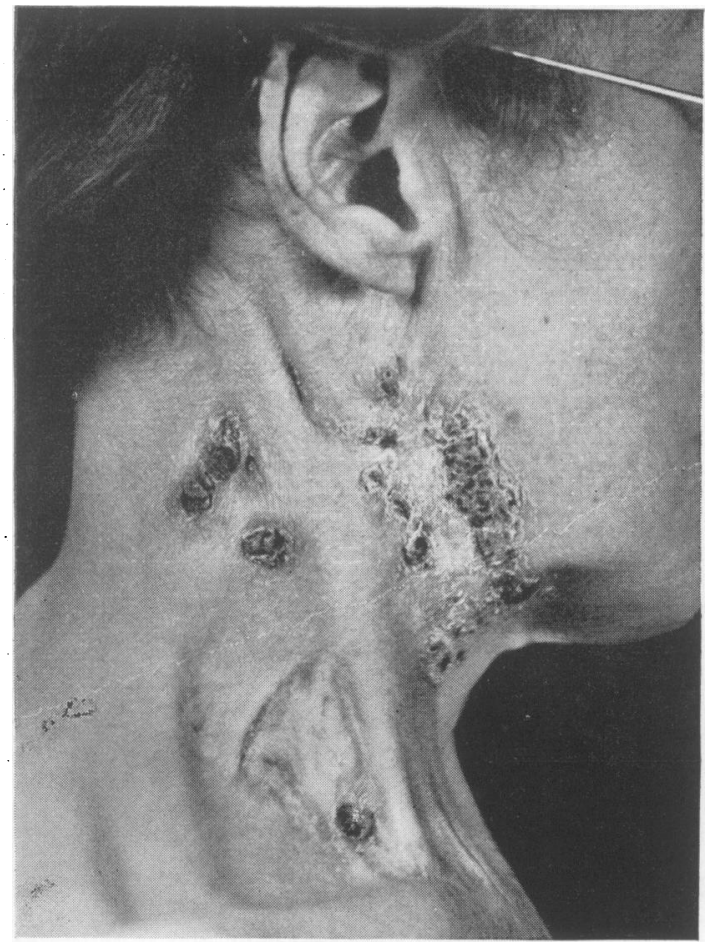

Fig. I

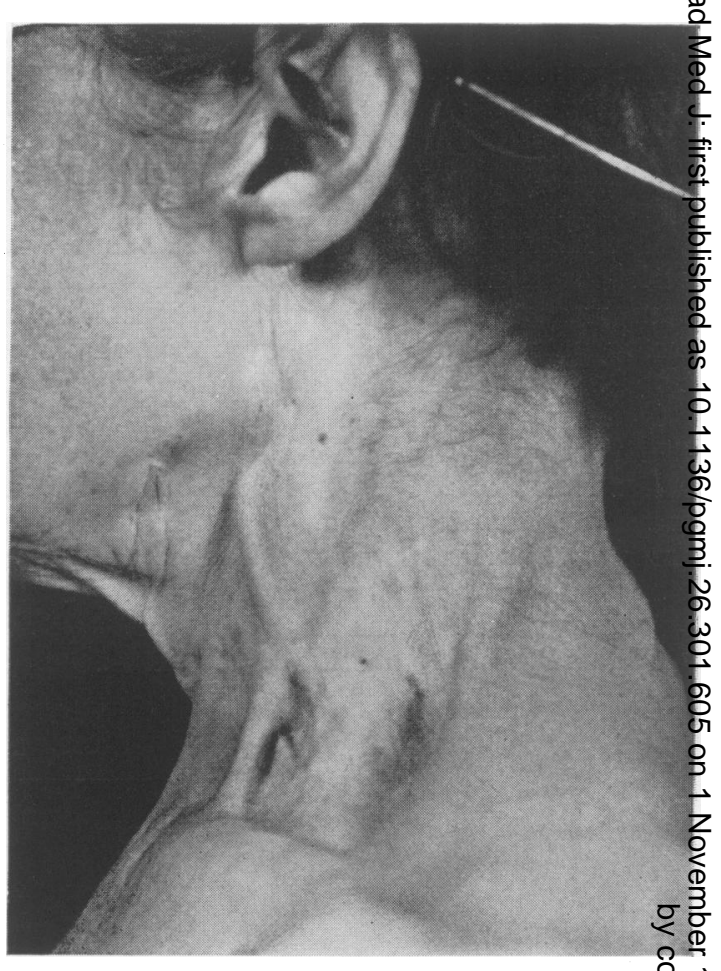

FIG. 2

Right and left sides of neck showing scarring, incrustation and sinuses, together with, on the left side, a mass of glands.

lous granulation tissue. This track was surrounded by a dense mass of hard collagenous fibrosis. Deep to this sinus was a matted mass of caseating tuberculous lymph nodes, the largest node being Io $\mathrm{mm}$. in diameter. Histologically the nodes were embedded in fibrous tissue. The central ones were largely destroyed by active caseous tuberculosis whilst the smaller peripheral ones showed only an odd tuberculous follicle or none at all. Acid-fast bacilli were found in this specimen.

The final specimen consisted of a small peritoneal nodule about $4 \mathrm{~mm}$. diameter. This consisted of a central mass of caseation surrounded by epitheloid cells and a few giant cells. Although we have so far failed to find acid-fast bacilli in this specimen, the histology is sufficiently typical to justify a confident diagnosis of tuberculosis.

\section{Discussion}

Prof. AIRD: Abdominal tuberculosis at this age is very unusual. The operative diagnosis in cases of generalized tuberculosis of the peritoneum can be very difficult and in this particular case the diagnosis offered a special difficulty because of the presence of a localized tumour, and of the presence of mucin-secreting cells in the peritoneal fluid. I know of no way, in a difficult case, of distinguish- ing at operation between miliary tuberculosis of the peritoneum on the one hand and multiple malignant nodules on the other. Several of us here sawo just such a case a few months ago and at operation were unable to make up our minds whether it was? malignant disease with an occult primary, or whether in fact it was a tuberculous peritonitis Dr. Harrison has given us a clear description and diagnosis but we shall be most interested to heary his further commentary.

M. R. EwING: When this lady first presented herself we made a diagnosis of tuberculous glandsi of the neck. Dr. Harrison unfortunately has nots been able to show us the type of cells which were obtained from the peritoneal exudate; they apparently were compatible with a diagnosis of malignant disease. We therefore made a further diagnosis of a mucus-secreting tumour within thes abdomen.

After laparotomy her wounds healed withoutN incident. The case therefore bears out the difficulty of establishing a diagnosis on naked eye appear ance of small nodules on the surface of the peritoneum. After operation we gave a bad prognosis? on the basis of our diagnosis of malignant disease, 0 but now, of course, the prognosis is considerablyo more favourable. We are proceeding with 


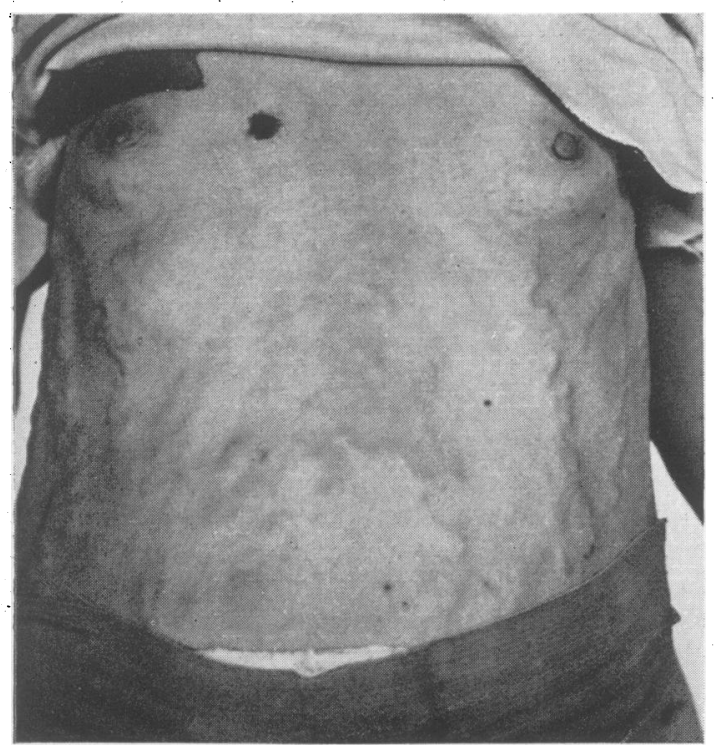

FIG. 3.-The abdomen showing distended veins in which the blood flow was upwards.

streptomycin therapy and hope to arrange sanatorium treatment.

DR. G. V. HARRISON: There are several interesting points from the pathological point of view. The original problem, concerning the peritoneal exudate, was a difficult one. There was no obviously malignant cells, nor were we able to find mucin in the cells. They could have been ordinary peritoneal phagocytes or mucin-secreting cells. There was certainly mucin but we have no way of telling whether it was connective tissue mucin or epithelial mucin and we felt obliged to suggest this suspicion of malignancy. As it turned out we were wrong. I recall a year or two ago I made a post-mortem examination on a middle-aged woman who died with almost generalized lymphnode tuberculosis without significant organ involvement. I would very much like to know the nature of the bacillus. If it is possible to get bacilli from the neck I should be interested to know if they are bovine.

M. R. Ewing: A culture has been sent for examination.

DR. HARRISON: I would gamble it is more likely to be bovine than human. Our last case was. I do not know where the inferior vena cava lesion comes in, unless she has had a growling tuberculosis in the glands. That is pure speculation of course.

Prof. AIRD: Inferior vena cava thrombosis is so

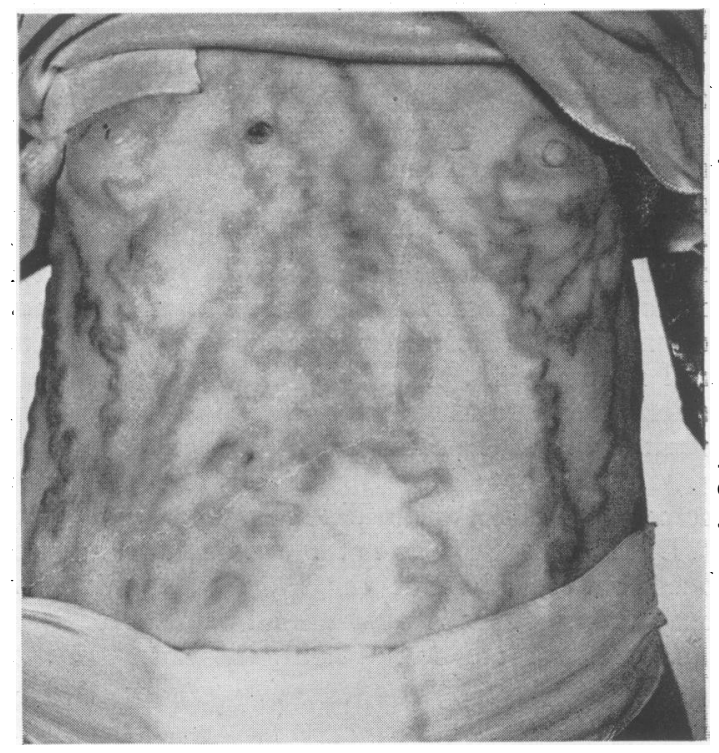

FIG. 4.-Infra-red photograph of the same.

rare a thing that there is a certain onus on us connect it with the tubercle.

M. R. EwING: Certainly it was quite unrelateq to pregnancy.

Mr. SELWYN TAYLOR: We had a discussion here last term concerning cases of tuberculous epididymitis and on that occasion it was pointed out how remarkably specific was tissue immunity to the tubercle bacillus. In this lady we have tuberculosis affecting the lymph nodes in her neck and axilla; perhaps then the primarily affected tissue in the abdomen was also the lymphatic glands. It is interesting to know because no one has really explained how the four main types of abdominal tuberculosis do arise. Perhaps they are all lymphatic in origin.

DR. HARRISON: I would think lymph-node infection in this case is almost certainly the source 의 of the peritoneal involvement. Once the infection reaches the glands it might well have little difficulty in getting through the capsule and into the serous cavity.

Mr. Selwy TAYLOR: Would you say most $\stackrel{N}{N}$ cases of abdominal tuberculosis we see are due to $\mathrm{\omega}$ lymph-node involvement?

Dr. HARRISON: It cannot be a truly primary $\stackrel{0}{c}$ lymph-node infection but all the cases one sees of $\mathbb{D}$ abdominal tuberculosis have involved lymph nodes. I have not seen one without.

Prof. AIRD: It is not true to say, then, that in 
primary tuberculosis lymph nodes are infected and in secondary tuberculosis they are not?

Dr. HARRISON: It is true but you have to look hard for it.

Mr. Winsbury-White: One small point; I noticed how much fibrosis there is in connection with this tissue removed from the axillary lesion, and it recalls to me that I have seen this in cases of tuberculosis of the testicle in elderly men. On one occasion I removed the testicle thinking it was a tumour and the microscope showed giant cells and no caseation. Here you have fibrosis in an elderly person and we have it in the urinary tract occasionally in the same way.

M. R. EwING: How do the cells of the follicles come to be called epitheloid cells?

Dr. HarRison: I do not know. They have also been endotheloid but the name has gradually been dropped. It is a traditional name.

Prof. Liege: I do not know the history of the origin but there is no doubt that they have an epithelial arrangement. If you take those histio- $\mathbb{D}$ cytic cells and grow them on a single surface they.. do take on an epithelial arrangement although they are not united to each other.

PROF. AIRD: You said there were no readily available methods of distinguishing between the two forms of mucin. Are there any at all?

DR. HARRISON: Mucin is not a single substance, $\stackrel{\mathbb{Q}}{\Omega}$ it is a remarkable mixture of protein and poly- के saccharides. Only a select few give a positive stain for mucicarmine; practically all of them give a positive metachromatic reaction with the various blue and violet dyes. Broadly speaking connective tissue mucin fails with mucicarmine and possibly with the metachromatic stains; but gastric mucin is also unsatisfactory with these two methods. I o do not think there is any way in which we can $\omega$ accurately distinguish them unless we have an adequate bulk in a test tube.

\section{HOW TO GET THERE}

An Address Book for the Medical profession, showing how to reach the various Colleges, Societies, Institutes and Hospitals in and near London. Third edition : 1950.

Published by the

FELLOWSHIP OF POSTGRADUATE MEDICINE
I Wimpole Street, London, W. I
Price 2s. 6d.

H. K. LEWIS \& Co. Ltd. Medical Publishers and Booksellers

Catalogues on request State interests

136 GOWER STREET LONDON, W.C. 1

(Adjoining University College and Hospital)

Telephone: EUSton 4282 (7 lines)

Telegrams : Publicavit, Westcent, London

Business hours: 9 a.m. to 5 p.m. Saturdays: 1 p.m.

\section{Medical Lending Library}

ANNUAL SUBSCRIPTION from ONE GUINEA

For the CONVENIENCE of POST-GRADUATE STUDENTS SHORT PERIOD SUBSCRIPTIONS ARE ARRANGED - for 3 or 6 months

Detailed Prospectus on application

The Library Catalogue revised to December, 1949, containing classified index of authors and subjects in preparation.

Bi-Monthly List of New Books and New Editions sent post free on request

NEW BOOKS ADDED IMMEDIATELY UPON PUBL!CATION 